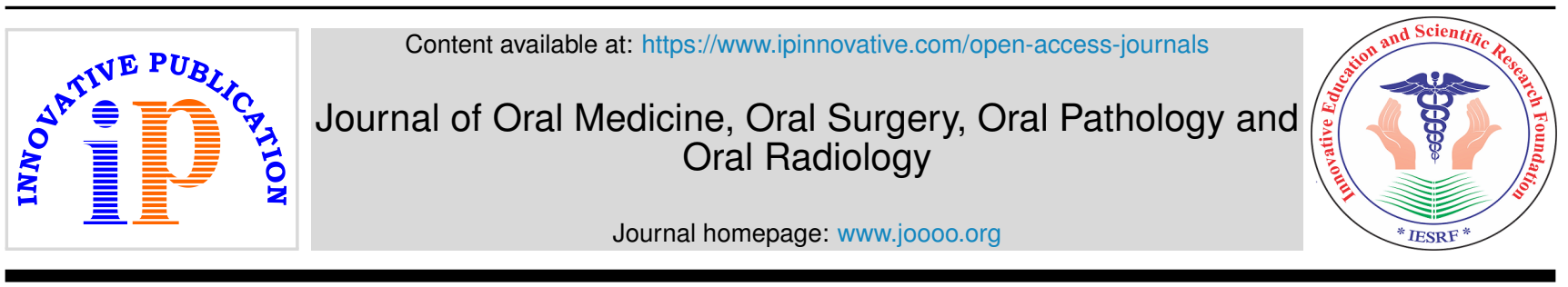

\title{
From the editors desk
}

\section{Private clinics can become your valued research labs}

\author{
Ketki Kalele ${ }^{\circledast 1, *}$ \\ ${ }^{1}$ Dept. of Oral Pathology \& Microbiology, V.Y.W.S Dental College and Hospital, Maharashtra, India
}

\section{A R T I C L E I N F O}

Article history:

Received 06-02-2021

Accepted 07-02-2021

Available online 18-02-2021
(C) This is an open access article distributed under the terms of the Creative Commons Attribution License (https://creativecommons.org/licenses/by/4.0/) which permits unrestricted use, distribution, and reproduction in any medium, provided the original author and source are credited.
New year greetings to all the professionals who just are not clinicians or academicians but are also enthusiastic learners!!!!

Let us hope that this new year brings with it great opportunities to learn more and expand more and open avenues wherein highly credible researches can bring out fruitful advancements in medicine to save lives....

Yes, the professional who fails to remain lifelong student soon perishes and until and unless research does not get imbibed in the core of each and every budding as well as established doctor the world would get devoid of much useful information....

It has been a notion for eons that scientific paper writing/research publications is meant only for the academicians or researchers and that too because having more paper publications in their CV's increase their chances of getting promoted or more salary and incentives or sometimes because it is mandatory for them to get published; and since it is not the case with private practitioners/clinicians they usually refuse to fall into the tedious cycle of writing down their data and going for publishing...

But, in todays editorial I would like to bring the point to the light that private hospitals, clinics or laboratories in some instances can prove to be a great source of genuine information of clinical data on disease and their therapeutic outcome. This is because, knowingly or unknowingly most

\footnotetext{
* Corresponding author.

E-mail address: drketkikalele@gmail.com (K. Kalele).
}

of the clinical and treatment related work takes place in these hospitals and clinics rather than in research labs and colleges or institutes....

Also, the clinicians many times use some innovative methods or try some different and new combinations of drugs or some altered dosages which actually work for the patients... The clinicians underestimate the research they just made with their innovative treatment protocol and this is how the society remains devoid of good treatment practice and the clinician gets devoid of getting credibility for his good work...

Publishing the work not only increase the credit and swell the portfolio of the professional but it also makes the professional upgradation of knowledge in the stream which is the key for survival in our field and inculcates research culture which is a one up point irrespective of the field of work...

"Publishing much valued clinical data from the private practise in good peer reviewed journals gives an opportunity to the clinicians to publicize their work on the world platform and growing from local to global!"....

Also, the scientific community would get benefited because data from clinics and hospitals are the results gained actually from the patient's responses to the treatment procedures or drugs (Phase IV) and not from cell lines or animal tests.... Hence, I feel that every clinician should treat his private setup just not as clinic or laboratory but as a research lab... 
In the end I would like to conclude my editorial by saying when we publish without any compulsion, the research is authentic and meaningful. Otherwise, just publishing a paper for the sake appraisal is of no use.

\section{Author biography}

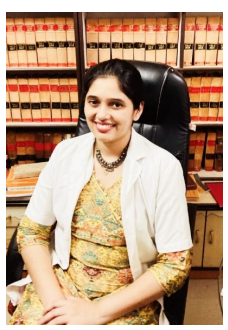

Ketki Kalele, Editor-in-Chief (JOOO)

Dept. of Oral Pathology \& Microbiology,

V.Y.W.S Dental College and Hospital,

Maharashtra, India (D) https://orcid.org/0000-
$0003-3627-142 x$

Cite this article: Kalele K. Private clinics can become your valued research labs. J Oral Med, Oral Surg, Oral Pathol, Oral Radiol 2021;7(1):1-2. 